systolic murmurs at the base of the heart. The short section on electro-cardiography is not illustrated.

Throughout the work, constant reference is made to published work and each chapter is followed by a list of up to 300 references. Dr. Bauer's bipartite career has made him familiar with both European and American sources, and the German literature is genertusly represented.

The book demonstrates the author's preoccupation with constitutional factors in the pathogenesis of disease. Although many of the views he presents on this subject are adequately demonstrated and well documented, some of his comments upon the major role of constitutional factors in conditions such as essential hypertension, 'constitutional' diabetes and hyperthyroidism represent his own intelligent reflection rather than scientifically proven fact. The concept of the " constitutional worth of an organ' is frequently used to explain its vulnerability as a site of complication in a general disorder. While this concept seems to have some validity, one would wish it more precisely characterized in physico-chemical terms before using it as extensively as does Dr. Bauer.

In fine it must be said that the book makes pleasant reading; it emanates the author's joy in the intellectual adventures of medicine.

H.K.

\section{ATLAS ZUR SPURENKUNDE DER ELEKTRIZITAT}

\section{(Atlas of the Traces of Electricity)}

By S. Jellinek. Pp. viii +78 , illustrated. Vienna : Springer-Verlag. I 955 .

This unique book has been prepared by an authority on this subject and by an enthusiast at that. Dr. Jellinek is professor at Vienna University, but some of his work was done at Oxford. The manifestations of the electrical current in its impact on living matter and on inanimate objects are briefly described and experiments to reproduce these effects were carried out. All this is illustrated by 199 pictures, many of them in colour.

The figures traced on the skin of men struck by lightning and in such articles as mirrors, branches of trees and conductors show a variety of diffuse or fern-like marks, but occasionally thin lines only develop. Muscle fibres undergo a curious torsion, and this occasionally affects also cell nuclei. The mechanical power of electric current may produce bursts, cuts or perforations. Sometimes a metallic oxide may stain the struck area if it heen near a metal. The patterns of necklaces or even of socks may be traced on the skins, producing tattoo-like marks.

The material of this collection is now displayed in an electro-pathological museum, cared for by the author. There is only one criticism about this book. The description of the pictures is completely divorced from the atlas part of the book and it is difficult to find the key, and a little irritating.

E.N.

\section{PRINCIPLES ANDD PRACTICE OF ANTIBIOTIC THERAPY}

By HeNRY Welch, in collaboration with 16 others. Pp. xix +699 . London: Interscience Publishers Inc. I954. \$12.00.

This large volume is worthy but, unfortunately, very dull. This is partly because it has been written not by one author only but by a team (of which every member happens to be very distinguished) and partly because it seems to be the editorial policy to be fair all round, to draw no comparisons between the different antibiotics, but to state as many facts as possible about all of them.

At times one feels the authors are positively leaning over backwards to avoid making any statement which might lead the reader to prefer one antibiotic to another. How can one reconcile these two paragraphs (occurring on consecutive pages!): 'There seems to be no question now that on rare occasions ... chloramphenicol causes serious blood dyscrasias.' 'It should be emphasized that it cannot be stated with finality that chloramphenicol ... actually caused the blood dyscrasia . . . following (its) use.'

The result, with its enormous number of references, must be very valuable to the pharmacologist, but is not very helpful to the practising clinician (for whom it was evidently intended). Much more practical guidance, for instance, might be given about the relative merits of different preparations of penicillin, and their relative dangers. The advantages of crystalline penicillin given in high dosage two or three times a day, over all longacting preparations, are not made clear (one is led to believe that the maintenance of a steady level of a bactericial drug is still considered an all-important consideration). A book of this sort might well include a separate chapter on the dangers and complications of antibiotic therapy. However, those who wish to consult a complete and up-todate summary of published work on the subject will find this book very helpful.

\section{RADIUM THERAPY: ITS PHYSICAL ASPECTS AND EXTENSIONS WITH RADIOACTIVE ISOTOPES}

By C. W. Wilson, M.Sc., Ph.D., F.Inst.P. Second edition. Pp. ix +286 . London: Baillière, Tindall and Cox Ltd. I956. 37s. 6d.

This book deals with the physical aspects of the local application of radium and radioactive isotopes in the therapy of cancer and is based on the very 
close collaboration between radiotherapist and physicist in this field.

The first edition appeared eleven years ago; the new edition has been brought up to date by the inclusion of recent developments and by many useful charts. The book is very valuable as a source of information to the postgraduate and as a guide to the radiotherapist and physicist.

\section{NEW CONCEPTS IN SURGERY OF THE VASCULAR SYSTEM}

By Emile Holman, M.D. Pp. v + 108, with 47 illustrations. Oxford: Blackwell Scientific Publications. 1955. I 8s.

Dr Holman has chosen a good title for his monograph, for it consists of two important lectures, each on a new aspect of a familiar problem. In the first he describes the dramatic changes which have taken place in treating arterial injuries, largely as a result of Korean experience. There the U.S. Army and Marine surgeons reduced the incidence of amputation very dramatically; where 70 per cent. of popliteal artery ligations in the wounds of World War II were followed by amputation in Korea, taking advantage of many favourable circumstances, popliteal artery reconstruction entailed amputation in only 20 per cent. Dr. Holman explains the possibility of reconstructive surgery on technical improvements since I945. It may, however, be that the peculiar conditions of the Korean campaign were as much a factor, for forward surgery was conducted behind a relatively static front, with effective helicopter rescue and evacuation of the moderate numbers of casualties.

In his second lecture Dr. Holman describes his own original work on the dynamics and structural changes in post-stenotic dilatation and in arteriovenous fistulae. He has not only reproduced many of these changes in vitro, so to speak, using physical apparatus only, but also correlates these and similar measurements taken in patients and experimental animals. An interesting hypothesis is produced that fatigue of the kind known to metallurgists also occurs in biological structures. No. direct physical evidence can yet be given but the theory does account for many of the strange phenomena of vascular disease.

A small annoyance to British readers will be the inaccurate account of what must be intended to mean the Farnborough tank tests of the Comet airliner, for, as is well known here, a cyclical stress was applied to the pressure cabin, not a constant unrelenting and high pressure, which indeed would not have been in any sense comparable to the life of this aircraft or indeed to the stress upon an artery either.

In all other respects this is a valuable and important monograph for it throws important new light on the damaged artery, its mode of late failure and its means of early cure. It should be read bs every surgeon.

H.H.G.E.

By G. E. Beaumont, M.A., D.M., F.R.C.P㞐 D.P.H. Pp. xiv +469 , with 74 illustration $\Omega$ London: J. \& A. Churchill Ltd. 1956. 45s. कి

This book consists of a series of case histories $\overrightarrow{0}$ In the first section these are drawn mainly from the author's private practice, and they tell not only of the problems of the patient, but also of the diffte culties that the consultant has to face in his dealing with colleagues and relatives. This provides for. the student a useful introduction to a less familia side of medicine. A second section deals witb cases of tuberculosis and of congestive heart failures Here the emphasis is primarily on the reactions of the patients to their illness. In the final sectio cases are presented by the Socratic method of Question and Answer.

The book sets out to achieve a number of pur= poses. In part it is Dr. Beaumont's personal memoirs, and introduces us to the teacher as wef as to his patients. It emphasises the humanity of patients, and thus forms a valuable counterbalaoce to the reading of standard text-books, and, finaty it also embodies much useful medical informativi Most of the latter is at a level best suited to unctero graduate needs; but some (as, for example, the section on spider naevi) will be useful also to posto graduates. The arrangement of the book reallo amounts to providing ward rounds in the library and as such it makes enjoyable and instructive reading.

\section{SEXUAL PRECOCITY}

By Hugh Jolly, M.A., M.D., M.R.C.P. Pp. xifit +276 , with 69 illustrations. Oxford: Blackwed Scientific Publications. 1955. 50s.

This book will not disappoint those who we롤 fortunate enough to hear Dr. Jolly present the material for his M.D. thesis to the British Paediatr黑 Association or to the Royal Society of Medicine. N

It includes the case-histories of the 69 children tracked down by the author with such care, as wef as a finely-produced collection of photographs and sections, $a^{+}$very full review of the world literatuge
and both an author and a subject index.

The material is well classified and most clearfy presented, while the discussion of treatment, pa\& ticularly the psychological aspects of management, is sensible and well balanced. Both paediatrician and endocrinologists will find this work invaluablo 